\title{
新形势下城市道路交通拥堵原因及对策分析
}

张鹏

\author{
秦皇岛市市政设计院
}

DOI:10.32629/btr.v3i2.2884

[摘 要] 伴随着我国城市化水平的不断提升,人们的物质生活质量得到明显提高。日常出行方式逐渐丰富,更多的私家车在城市道路上出现,交 通需求量明显上升。城市交通供需关系日益紧张, 逐渐成为城市发展的重要问题, 导致我国很多城市出现严重的交通拥堵现象。基于此, 本文主 要探讨了新形势下城市道路交通拥堵原因和解决对策。

[关键词] 新形势; 城市道路; 交通拥堵; 治理措施

\section{1 新形势下城市交通拥堵的原因}

1. 1 道路容量

近些年来, 我国城市经济发展水平显著提升, 道路上行驶车辆数量日 益增加, 私家车占据机动车比例逐渐增大。随着人们消费观念的转变, 人们 逐渐重视自身物质和精神层面享受, 道路交通车辆出现明显上涨的趋势, 可是由于道路容量的限制, 并不能充分满足日益增大的交通需求, 导致城 市交通道路出现拥堵的情况。

\section{2交通参与者素质不高}

城市市民交通安全意识很薄弱, 人行天桥等设施并不能充分发挥出该 有的作用, 行人横穿马路的现场时有发生, 城市站到停车问题很严重, 车辆 通行效率比较低; 三轮车等路边揽客问题严重, 车辆随意停放也加重了交 通拥堵; 驾驶员的安全意识薄弱, 甚至会出现逆向停车等交通违法行为, 由于简易流程的交通事故处理不到位, 造成大面积的拥堵问题 ${ }^{[1]}$ 。

\section{3 交通规划建设}

城市规划建设要具有一定的前瞻性。可是, 相关政府部门并没有重视 交通长期规划, 在城市中心地区, 比较繁华的商业道路出现严重的交通拥 堵现象。因此, 相关部门要加大城市化管理力度, 重视城市交通规划中的中 远期发展。可是, 当前我国很多城市并没有针对交通长期规划方面的研究, 没有针对性对各路段进行分析研究, 是很多道路交叉口比较复杂, 由于规 划不合理导致道路交通拥堵现象严重。随着城市进程逐步加快, 很多大城 市或超大城市的交通拥堵现象逐渐严重, 通过现代化的交通工具可以加强 道路通行能力, 有效的解决城市日益严重的拥堵问题 ${ }^{[2]}$ 。

\section{2 新形势下城市道路交通拥堵的处理措施}

2. 1 合理规划, 优化布局

科学规划城市道路交通, 坚持规划先行的原则, 道路规划要跟随社会 发展的步伐, 同时做出及时的调整, 顺应时代发展趋势。冲破单一部门的大 包大揽居民, 坚持政府带头, 联合公安交通管理部门、交通建设部门和市政 工程部门等相关部门, 充分调动部门的积极性, 根据各部门具体工作内容, 做出长期的规划方案。应用交通大数据服务城市交通总体规划, 不断完善 城市道路网络, 改善道路微循环能力, 缓解城市土地开发强度, 做到还路于 民, 科学降低中心区域建设密度和强度, 从而环节交通拥堵压力。通过科学 规划中心区域的政治、文化、经济、商业、服务等内容, 全面改造城市主 体道路交汇口。坚持发展性和前瞻性的思维方式, 全面掌握节点和关键拥 堵点的症状, 对症下药, 彻底解决道路交通拥堵问题。

2. 2 加强智能化交通设施建设
伴随着科学技术的深入发展, 智能化交通运输系统逐渐成熟。利用信 息技术和电子传感技术、计算机处理技术等, 综合处理交通运输问题。通 过智能交通运输系统使出行计划更加透明和及时, 方便人们选择最佳的出 现路线和实践, 进而实现交通道路利用率的提升 ${ }^{[3]}$ 。

2.3 大力发展公共交通

城市交通发展过程中要坚持绿色出行和环保节能的理念, 大力推行城 市公共交通、轨道交通等, 通过设立公交车专用道、潮汐专用车道、合乘 车道等, 确保公交交通建设。不断完善城市公共交通配套设施, 改善城市公 共交通管理制度, 构建城市公共交通法规标准, 重视有效的监督和管理, 吸 引更多市民选择公共交通出行, 从而提升道路利用率, 有效的环节交通拥 堵问题。利用大数据技术对道路节点进行科学分析, 构建交通枢纽站和换 乘枢纽, 科学规划公交路线, 充分实现区域一体化和零距离换乘的目标, 通 过优化公交运行线路, 实现道路资源的合理配置。

2. 4 加强交通宣传和普法教育, 建立良好的交通秩序

道路交通作为人、车、路的统一体, 三者缺一不可需要每一个交通参 与者维护良好的交通秩序。在新形势下, 要不断提升市民交通素质, 坚持多 措并举的原则。提升市民交通素质不但需要通过技术手段, 同时要坚持开展 教育和制度引导。通过微信公众号、抖音公众号、支付宝生活号等平台, 为 交通安全宣传提供课程视频、资料查阅等版块, 为市民提供学习机会, 不断 提升自身的知识水平。通过大数据信息技术, 在网站、APP等平台曝光交通 违法行为和不良驾驶行为, 从而震慑交通违法行为。通过电台、电视台、报 纸等媒介, 实施专题讲座和交通知识竞赛等活动, 从而为居民提供更深入 的交通管理教育。重视交通制度的构建, 维护交通法律法规权威。

\section{3 结束语}

伴随着我国城市化水平的提升, 城市化进程日益加快, 在这种背景下, 交通道路拥堵成为了重要的发展问题。在社会经济快速发展的趋势下, 通 过研究城市道路交通拥堵原因, 制定出科学的解决措施, 有效的解决城市 道路交通拥堵问题, 改善城市交通环境, 促进我国城市化水平的显著提升。

[参考文献]

[1]黄亮彪,张艳.城市道路交通拥堵的原因及其治理对策[J].政法学 刊,2007,24(1):114-118.

[2]徐超忠. 基于移动大数据的城市交通拥堵对策研究 [J]. 交通运输部 管理干部学院学报,2015,12(4):16-20.

[3]王小平. 大数据背景下深圳治理交通拥堵创新对策研究 [D]. 武汉: 华中师范大学,2016. 